\title{
Studi Analisis Fenomena Sosial Keagamaan "Duta" di Kota Kayuagung Kabupaten OKI
}

\author{
Eva Kharisma \\ Fakultas Dakwah dan Komunikasi \\ Universitas Islam Negeri Raden Fatah Palembang \\ E-mail: evakharisma_uin@ radenfatah.ac.id
}

\begin{abstract}
Abstrak
Penelitian ini berjudul "Studi Analisis Fenomena Sosial Keagamaan Terhadap Profesi Duta di Kota Kayuagung Kab. OKI". Kayuagung merupakan generasi pemula yang memulai karir menjadi duta, karena pada masa itu peraturan untuk melakukan perjalanan ke luar negeri belum secanggih sekarang, maka banyak dari para pemuda asal Kayuagung yang berangkat ke luar negeri untuk berkarir menjadi duta. Meskipun tingkat pendidikan mereka sangatlah rendah bahkan ada yang buta huruf, namun hal tersebut tidaklah menjadi kendala keberhasilan mereka dalam berkarir menjadi duta. Tujuan diadakannya penelitian ini adalah untuk mengetahui eksistensi para duta di Kota Kayuagung, mengetaui faktor-faktor apa saja yang melatarbelakangi kemunculan duta yang ada di Kota Kayuagung dan mengetahui bagaimana fenomena sosial keagamaan duta yang ada di Kota Kayuagung ini. Metode yang digunakan dalam penelitian ini adalah : deskriftif kualitatif, yakni dengan mengumpulkan data-data dari lapangan yang berkaitan dengan pokok permasalahan dalam penelitian, kemudian penulis analisa dengan cara induktif kualitatif yaitu penyusunan data dari khusus ke umum. Adapun informan dalam penelitian ini adalah para duta yang ada di Kota Kayuagung yang berjumlah 5 orang. Tehnik pengumpulan data yang digunakan dalam penelitian ini adalah : observasi dan wawancara. Hasil penelitian menunjukkan bahwa para duta di Kota Kayuagung sangat diterima oleh masyarakat. Hal ini dibuktikan dari hasil wawancara yang menunjukkan bahwa para duta mempunyai sifat kedermawanan, ada juga sebagian masyarakat yang ingin ikut bergabung setelah mendengar keberhasilan mereka, dan mereka juga disebut sebagai pahlawan devisa. Adapun faktor-faktor yang melatarbelakangi kemunculan duta yang ada di Kota Kayuagung ini antara lain yaitu faktor ekonomi, tuntutan gaya hidup yang semakin mewah, tekanan adat dan budaya serta pola pikir masyarakat yang masih kurang. Sedangkan fenomena sosial keagamaan para duta adalah melaksanakan acara yasinan dan do'a sebelum meaksanakan keberangkatannya, mendatangi para ulama untuk minta dido'akan, serta membantu para masyarakat yang membutuhkan dan membangun masjid, sekolah, dan jalan yang ada di lingkungan mereka, dan merekapun memberikan sumbangan ke masjid dan pantipanti asuhan.
\end{abstract}

Kata Kunci : duta, sosial, keagamaan

Manusia sebagai makhluk religius berkedudukan sebagai abidullah dan khalifatullah di muka bumi. Tugas manusia untuk mengolah dan memakmurkan alam ini sesuai dengan kemampuannya untuk kesejahteraan umat manusia, serta menjadi rahmat bagi orang lain atau yang disebut rahmatan lil'alamin. Berbagai penemuan dan kemajuan teknologi berperan besar terhadap perubahan kebudayaan dan sikap manusia.

Manusia semakin termanjakan dengan dengan kreatifitas penemuannya sendiri bahkan memuja ciptaannya sendiri. Dengan sifat manusia yang konsumtif banyak kebutuhan yang harus dipenuhi.Kemajuan seperti itu ternyata tidak selamanya membuat 
manusia bahagia, tenang, dan aman. Berbagai persoalan ikut menyertai kemajuan peradapan manusia itu, mulai dari persoalan lingkungan hidup, seperti perampokan, pemerkosaan, penculikan, serta pembunuhan yang kian akrab terjadi dalam keseharian. Sehingga, tanpa mereka pikirkan lagi bahwa tindakan dan kejahatan yang mereka lakukan dapat merugikan diri sendiri, orang lain, masyarakat, bangsa bahkan negara (Soekanto, 2004).

Namun, berbeda dengan kehidupan zaman sekarang, nilai-nilai keagamaan telah banyak dilupakan oleh manusia, sehingga menimbulkan penyimpangan pada masyarakat, kriminalitas meningkat dengan sangat tajam. Dapat dilihat dari data kualitatif pada tahun 2011 sampai 2013, yang mana pada tahun 2011 masalah kiminalitas yang ada di Indonesia sebanyak 347.605, kemudian pada tahun 2012 turun sekitar 1,85\% (persen), tetapi pada tahun 2013 kemarin angka kenaikan kriminalitas menaik sebanyak $0,27 \%$ (persen). Sejauh ini, kenaikan dan penurunan tindak kriminal cenderung kecil, tetapi rata-rata tingkat kriminalitas di Indonesia masih sangat tinggi. Perampokan dengan menggunakan senjata tajam bahkan senjata api pun, tidak hanya terjadi kota-kota besar dan tempat ramai tetapi sudah menyebar dimasyarakat pedesaan (Margiono, 2011)

Adapun tokoh- tokoh perampok dunia beserta motif-motif kejahatan yang dilakukannya, antara lain Colton Harris, ia telah diduga mencuri 5 (lima) pesawat, beberapa mobil dan perahu, Billy The Kid (William Henry McCarty), ia adalah seorang pencuri kuda di Arizona dan pencuri ternak di New Mexico, Salvatore Giuliano, ia disebut sebagai Robin Hood dari Sisilia, ia menjadi penjahat paling terkenal pada sejarah Italia karena keangkuhan dan kedermawanannya. Ia memimpin sekelompok pasukan yang dilaporkan sebanyak 600 orang dalam perampokan tuan tanah kaya yang hasilnya diberikan kepada orang miskin, Butch Cassidy ia menamakan dirinya dalam geng "Wild Bunch", ia merampok lusinan kereta dan merampok ribuan dolar dari kereta pengiriman uang di Union Pasific.

Namun, perampokan tidak hanya terjadi diseluruh dunia bahkan di Indonesia pun banyak yang menjadi pelaku dan korban perampokan. Adapun nama-nama perampok yang ada di Indonesia antara lain Kusni Kasdut, ia adalah perampok spesialis barang antik, Slamet Gundul adalah bos kawanan perampok bank-bank yang ada di Pulau Jawa, selanjutnya ialah Johny Indo ia adalah seorang perampok yang kemudian insyaf dan menjadi pendakwah beserta pemain film.

Selain itu, bahkan tidak terkecuali di Sumatera Selatan banyak sekali terdapat nama-nama kelompok kejahatan antara lain, bajing loncat, begal, dan tujah. Namun, terdapat di salah satu kecamatan yang ada di dalam provinsi Sumatera Selatan, tepatnya di Kota Kayuagung yang lebih di kenal sebutannya sebagai "duta”. Dilihat dari sisi mata pencaharian penduduk Kota Kayuagung umumnya adalah pegawai, petani, disamping sebagai pengrajin pada industri kecil dan pertukangan. Mengingat daerah ini tidak 
banyak didirikan industri-industri besar serta didukung oleh sumber daya alamnya (minyak, gas dan batu bara) yang tidak banyak, maka sebagai ibu kota kabupaten, Kayuagung tidak banyak mengalami perkembangan.

Dengan keadaan demikian, tidak mengherankan kalau masyarakat Kayuagung hingga saat ini masih banyak pergi merantau, guna mencari nafkah bagi keluarga dan mempertahankan hidupnya. Akan tetapi, yang dimaksud dengan "mencari nafkah" disini bukan dalam artian ikut menjadi seorang TKI (Tenaga Kerja Indonesia) secara legal yang bekerja di pabrik-pabrik, perkebunan, atau pembantu rumah tangga (PRT), melainkan mencari nafkah sebagai bandit di luar negeri atau dalam bahasa Kayuagungnya lebih akrab dikenal dengan sebutan duta, yang tentunya pekerjaan tersebut erat hubungannya dengan dunia kriminalitas, seperti mencopet, mencuri, menjambret, bahkan merampok.

Kendati menurut pandangan ajaran agama Islam, tindakan dan perilaku para duta ini tergolong ke dalam perbuatan yang dilarang dan bertentangan dengan aturan- aturan yang ada didalam nash al-Quran dan Hadits, namun kenyataannya dalam realita sosial, banyak fenomena religius yang turut mewarnai dan melengkapi eksistensiannya sebagai pelaku kriminal sekaligus sebagai seorang muslim yang taat menjalankan agamanya, yang dapat dilihat dari kehidupan sehari-harinya, dengan datang kemasjid ikut sholat berjama'ah, menjalankan puasa di bulan ramadhan, melaksanakan sholat jum'at dan ikut serta dalam kegiatan-kegiatan keagamaan yang ada di sekitar tempat tinggal mereka bahkan naik haji dan menaikkan haji keluarganya.

Selain itu, bagaimana ketika seorang duta akan berangkat ke negara tujuannya, beberapa diantaranya ada yang mengadakan acara yasinan yang diadakan oleh keluarganya dengan mengundang masyarakat desa atau mendatangi seorang kyai untuk didoakan, yang mana kyai dan masyarakat yang ada disana juga ikut serta membantu dalam melaksanakan acara tersebut. Namun, tidak hanya keberangkatannya saja, kepulangannya pun selalu ditunggu-tunggu oleh masyarakat, karena bagi mereka para duta ini adalah pahlawan yang bisa membantu masyarakat, dengan cara membangun jalan, membangun masjid, dan juga ikut menyumbang untuk warga yang miskin.

\section{Eksistensi Duta di Kota Kayuagung}

Dari hasil penelitian yang dilakukan oleh penulis, bahwa ke- eksistensian duta yang ada di Kota Kayuagung ini sangatlah berpengaruh besar bagi masyarakat dan mereka juga diterima di lingkungan masyarakat, baik itu masyarakat Kota Kayuagung sendiri maupun diluar lingkungan Kota Kayuagung.

Adapun hasil kesimpulan dari kelima informan dapat penulis sampaikan, yaitu: 
Eva Kharisma

Studi Analisis Fenomena Sosial Keagamaan "Duta"

di Kota Kayuagung Kabupaten OKI

1. Keberadaan di lingkungan

Keberadaan para duta ini di dalam lingkungan masyarakat sangatlah diterima oleh masyarakat, khusunya masyarakat yang ada di Kota Kayuagung, karena sifat kedermawanan yang mereka miliki.

Masyarakat yang ingin bergabung setelah mendengar keberhasilan menjadi duta

Ada sebagian dari masyarakat setelah medengar keberhasilan mereka, maka mereka tertarik untuk ikut bergabung mnejadi duta. Namun, kebanyakan mereka yang hanya penasaran atau ingin tahu saja bagaimana menjadi seorang duta.

2. Sebagai pahlawan devisa

Sebutan sebagai pahlawan devisa yang diberikan oleh masyarakat, dikarenakan kedermawanan yang mereka miliki, dengan cara membantu pemerintah dan masyarakat melalui pembangunan-pembangunan yang ada di Kota Kayuagung, dan juga menambah APBD yang ada di Kota Kayuagung.

3. Peran duta senior

Bagi mereka peran para duta-duta senior yang diberikan kepada mereka sangatlah besar, mereka banyak sekali membantu mereka baik secara materi maupun spritual.

4. Pantang beroperasi di negara sendiri

Dari kelima informan jawaban yang mereka berikan hampir sama, mereka mengatakan apabila mereka beroperasi di negara mereka sendiri, sama saja mereka makan daging mereka sendiri.

\section{Faktor-Faktor Yang Melatarbelakangi Kemunculan Duta di Kota Kayuangung}

Dari hasil wawancara penulis kepada kelima informan dapat diambil kesimpulan bahwa, faktor utama yang melaterbelakangi kemunculan duta di Kota Kayuagung ini dikarenakan faktor perekonomian masyarakat yang sangat minim, sehingga mereka nekad untuk menjadi seorang duta. Dapat penulis simpulkan dari pertanyaan-pertanyan yang penulis berikan kepada informan bahwa:

1. Faktor utama ingin menjadi seorang duta

Mereka menjelaskan bahwa faktor utama mereka nekad menjadi seorang duta dikarenakan faktor ekonomi keluarga mereka yang serba kekurangan.

2. Gaya hidup yang semakin mewah

Dengan adanya gaya hidup yang seakan-akan sudah menjadi kewajiban untuk dipenuhi, maka ini juga menjadi keharusan bagi para duta untuk mencari uang lebih banyak lagi, agar bisa terpenuhnya keinginan mereka untuk mewujudkan itu.

3. Tekanan adat dan budaya yang ada di Kota Kayuagung

Kota Kayuagung yang dikenal memiliki banyak adat istiadat saat akan mengadakan suatu upacara tertentu, baik itu dari upacara pernikahan sampai kematian, yang setiap upacara itu memiliki ciri khas tersendiri bagi mereka yang ada di Kota Kayuagung, yang tentunya berhubungan dengan biaya yang cukup besar agar bisa terlaksananya adat istiadat atau acara-acara tersebut. Dan ini juga menjadi suatu keharusan bagi para duta yang ada disana. 
4. Karena pemahaman keagamaan yang sempit

Sebagian dari mereka ada juga yang mengenal bagaimana Islam itu yang sebenarnya, mengetahui salah benarnya, dan mengetahui halal dan haramnya. Namun, bagi mereka faktor ekonomi mereka seakan-akan memuntut mereka untuk nekad menjadi seorang duta, mereka juga mengatakan hasil yang mereka peroleh itu nantinya bisa disucikan, dengan cara mereka memberikan kepada yang membutuhkan untuk dipergunakan dengan cara yang baik, dan juga mereka selalu menyumbangkan kemasjid-masjid yang ada disekitar tempat tinggal mereka.

5. Karena paksaan dari keluarga ataupun pihak lain

Mereka mengatakan sama sekali tidak ada paksaan dari pihak manapun, baik itu keluarga maupun orang lain. Mereka nekad menjadi seorang duta karena keinginan mereka sendiri, yang ingin merubah tingkat kesejahteraan hidup hidup mereka dan keluarga mereka.

\section{Fenomena Sosial Keagamaan Duta di Kota Kayuagung}

Fenomena sosial keagamaan duta di Kota Kayuagung ini banyak terdapat hal-hal yang unik yang mewarnai ke-eksistensiannya terutama hal yang menyangkut dengan perpaduan antara yang halal dan yang haram atau antara yang hak dan bathil.

Dari hasil wawancara penulis kepada kelima informan, penulis mengajukan pertanyaan-pertanyaan yang mengenai tentang fenomena sosial keagamaan para duta ini, antara lain dapat disimpulkan jawaban-jawaban dari kelima informan ini, yaitu:

1. Yasinan dan do'a sebelum keberangkatan

Mereka menjelaskan bahwa saat mereka akan menjalankan misi mereka ke negara tujuannya, maka sebelum keberangkatan, mereka mengadakan ritual sedekahan yaitu yasinan, dengan mengundang masyarakat, pemerintahan setempat seperti RT, Lurah, Camat dan para ulama-ulama setempat. Namun, dengan perkembangnya kemajuan zaman, ritual ini sudah jarang ditemui, biasanya apabila mereka akan berangkat ke negara tujuan, mereka hanya mendatangi ara ulam-ulama atau kyaikyai yang ada disekitar tempat tinggal mereka.

2. Menjalankan ibadah sebagai seorang muslim

Sebagai seorang muslim, mereka menjelaskan tentu mereka menjalankan kewajiban mereka, walaupun terkadang sering kelalaian dalam melaksanakan shalat maupun ibadah yang lainnya, namun mereka tidak pernah lupa akan kewajiban mereka.

3. Melaksankan shalat jum'at dan sholat berjamaah kemasjid

Mereka menjelaskan bahwa mereka selalu menjalankan sholat jum'at dan shalat berjamaah kemasjid, walaupun sebagian juga dari mereka yang tidak sempat untuk melaksanakan shalat berjamaah, namun mereka teta menjalankan shalatnya.

4. Tingkat kepedulian terhadap masyarakat yang membutuhkan bantuan

Dijelaskan oleh mereka, hampir setiap kepulangan mereka dari merantau (menjadi duta) banyak sekali masyarakat setempat yang berdatangan kerumah untuk 
meminjam uang, mereka mengatakan uang tersebut untuk keperluan sehari-hari. Para duta pun selalu memberikan bantuan kepada mereka yang membutuhkan tersebut.

5. Hal yang bermanfaat yang telah diberikan

Banyak sekali hal bermanfaat yang telah mereka berikan kepada warga masyarakat, anatar lain mereka sealu menyumbangkan hasil dari mereka menjadi duta kemasjidmasjid yang ada disekitar tempat tinggal mereka, mereka juga membangun masjid, membantu memperbaiki jalan dan sekolah, mereka juga menyumbangkan pengahasilan mereka kepada panti- panti asuhan yang ada disekitar tempat tingggal mereka maupun diluar tempat tinggla mereka.

Dari kesimpulan diatas bila dikaitkan dengan teori yang dipakai oleh penulis yaitu teori psikoanalisis yang diperkenalkan oleh Sigismund (Sigmund) Schlomo Freud (1868-1939), ia menunjukkan suatu sistem kepribadian manusia terdiri dari id, ego dan superego.

Dimana id merupakan suatu sistem kepribadian yang sangat orisinil. Orisinil ini mengandung pengertian bahwa id ini merupakan bawaan sejak lahir (herediter) dan semua manusia memilikinya. Sejak mereka lahir mereka dikuasai oleh $i d$. Id adalah sumber naluri dan kurang terorganisasi. Pada dasarnya selalu mencari kesenangan dan kepuasan dan menolak segala bentuk rasa sakit. Karena beorientasi pada kesenangan semata, maka sering kali id ini mempunyai sifat yang tidak logis dan amoral. Id dimotivasi oleh dua insting dasar yaitu insting seksual dan insting agresif dimana Freud sering kali menyebutnya sebagai insting distruktif. Letak id berada dibawah alam sadar manusia.

Selain itu, ego selalu berhubungan dengan dunia nyata. Dalam diri manusia, ego mempunyai sifat untuk memerintah, mengendalikan dan mengatur kehidupan seseorang. Hal ini menunjukkan bahwa peran ego adalah sebagai mediator yang melakukan kontrol terhadap sifat id yang buta dan amoral. Karena berhubungan dengan dunia nyata, maka sifat ego ini adalah logis dan bertindak realistis, dengan kata lain, ego akan menjadi penengah antara $i d$ dan dunia nyata.

Sedangkan superego memiliki kode moral dan pertimbangan hukum.hal ini mengarahkan superego untuk berbicara tentang nilai-nilai seperti baik dan buruk, benar atau salah, panatas atau tidak pantas. Superego meletakkan segala sesuatunya tidak berdasarkan pada kesenangan tetapi pada kesempurnaan. Hal ini mengartikan bahwa superego berbicara tentang budaya dari pada berbicara tentang kebutuhan-kebutuhan biologis semata.

Maka jika dilihat dari penjelasan diatas dapat dikaitkan mengenai para duta yang ada di Kota Kayuagung bahwa, dimana setiap manusia khusunya para duta sudah memiliki kebiasaan sejak lahir untuk selalu mencari kesenangan dan kepuasan tanpa memikirkan dampaknya. Mereka nekad untuk menjadi duta karena ingin memenuhi kebutuhan mereka dan kepuasan dunia mereka, dan menyengkut tentang nilai-nilai yang 
ada di dalam kehidupan masyarakat seperti baik dan buruk, benar atau salah sesuatu yang mereka lakukan itu.

\section{Kesimpulan}

Kesimpulan yang dapat penulis ambil berdasarkan uraian diatas adalah sebagai berikut:

Pertama, Eksistensi para duta sangat diterima oleh masyarakat di lingkungan mereka maupun diluar lingkungan mereka, karena kedermawanan dan membantu pemasukan bagi pemerintah sampai mereka disebut sebagai pahlawan devisa. Eksistensi para duta dipengaruhi juga oleh peran duta-duta senior yang memberikan bantuan secara materi dan moril. Kedua, Faktor-faktor yang melatarbelakangi kemunculan duta disebabkan karena adanya: a. Tekanan ekonomi; b. Gaya hidup yang mewa; c. Pola pikir; dan d. Tekanan adat dan budaya yang ada di Kota Kayuagung. Dan ketiga, Fenomena sosial keagamaan duta di Kota Kayuagung dimulai dari proses keberangkatan dan kepulangan mereka, adapun hal-hal yang terjadi yakni: a) Melakasanakan yasinan dan do'a sebelum melaksanakan misinya; b) Mendatangi ulama-ulama atau kiyai untuk mintak dido'akan; b) Masih taat menjalankan ibadah sebagai seorang muslim c. Ikut bergabung pada acara-acara di masjid; dan d. Membantu warga yang membutuhkan bantuan 
Eva Kharisma

Studi Analisis Fenomena Sosial Keagamaan "Duta"

di Kota Kayuagung Kabupaten OKI

\section{Daftar Pustaka}

Brata Surya, Sumardi. 1983. Psikologi Kepribadian. Jakarta: Raja Grafindo Persada. Al-Fatah. 2012. Duta Versus Ulama. Palembang: Lembaga Pengabdian Masyarakat. Hartono, Soedarmadji. 2012. Psikologi Konseling. Jakarta: Kencana.

Margiono. 2011. Akidah Akhlak 2 (Kelas XI Madrasah Aliyah). Bogor: Yudhistira.

Moleong, Lexy G. 2001. Metodologi Penelitian Kualitatif. Bandung: Remaja Rosda Karya.

Nasution, Haruni. 1985. Islam di Tinjau Dari Berbagai Aspeknya. Jakarta: UI Press.

Sabera Adib, Helen. 2015. Metode Penelitian. Palembang: Noerfikri.

Soekanto, Soerjono dkk. 2004. Kriminologi Suatu Pengantar, Jakarta: Ghalia Indonesia.

www.bh4kt1.multiply.com/journal/item/58/Salah-Tangkap Hukum yang Salah- Kaprah Salah-Tangkap Juga Dapat Dipidana!

www.alsofwah.or.id/index.php?pilih=lihatkajian\&parent id=2098\&parent section=kj073\&idjudul $=1990$

www.gp-anshor.org/tajuk/salah-tangkap-dan-kesalahan-berjamaah.Html.Senin 25 mei 2015

www.koran.kompas.com/read/xml/ 2015/09/ 06/00140018/ salah Tangkap dan salah. Menghukum

www.mediaindonesia.com/read/2015/12/12/48989/70/13/Kasus Salah Tangkap dan_Asas_Legalitas

www.merdeka.com/peristiwa/kasus-kasus-korban-salah-tangkap-polisi-yang- palingmenyedihkan/ andro -salah-tangkap-disiksa-dipenjara-dan-diganti- rugi-rp-1juta.html diakses tanggal 22 April 2015 